\title{
A lionfish (Pterois miles) invasion has begun in the Mediterranean Sea
}

\author{
Demetris Kletou ${ }^{1,2^{*}}$, Jason M. Hall-Spencer ${ }^{1,3}$ and Periklis Kleitou ${ }^{2}$
}

\begin{abstract}
Until now, few sightings of the alien lionfish Pterois miles have been reported in the Mediterranean and it was questionable whether the species could invade this region like it has in the western Atlantic. Here, we present evidence from divers and fishermen that lionfish have recently increased in abundance and within a year colonised almost the entire south eastern coast of Cyprus, likely due to sea surface warming. At least 23 different fish are reported of which 6 were removed. Groups of lionfish exhibiting mating behaviour have been noted for the first time in the Mediterranean. Managers need this information and should alert stakeholders to the potential ecological and socio-economic impacts that may arise from a lionfish invasion. Actions could involve incentives to engage divers and fishermen in lionfish removal programmes, as these have worked well at shallow depths in the Caribbean. Given that the Suez Canal has recently been widened and deepened, measures will need to be put in place to help prevent further invasion.
\end{abstract}

Keywords: Lionfish, Pterois miles, Biological invasion, Non-indigenous, Alien species, Mediterranean Sea

\section{Introduction}

The Mediterranean Sea represents around $0.82 \%$ area and $0.3 \%$ volume of the world ocean but it contains 4$18 \%$ of described marine organisms and is a biodiversity hotspot with estimated 17,000 species (Coll et al. 2010). Mediterranean ecosystems face multiple anthropogenic threats such as climate change, over fishing and alien invasions (Kletou \& Hall-Spencer 2012). Mediterranean seawater temperatures are steadily increasing, and alien species are spreading, causing community shifts and tropicalization (Lejeusne et al. 2010; Montefalcone et al. 2015). There are now $>1000$ alien species in the Mediterranean and the majority are thermophilic species that have entered the eastern basin through the Suez Canal (Katsanevakis et al. 2014). Recent enlargement of this canal coupled with sea surface warming is raising concerns that this problem will get worse (Galil et al. 2015).

Lessepsian fish invasion rates are now increasing rapidly; ca $40 \%$ of the 130 alien fish species now living in the Mediterranean have been reported since

\footnotetext{
* Correspondence: dkletou@merresearch.com

${ }^{1}$ School of Marine Science and Engineering, Plymouth University, Plymouth, UK ${ }^{2}$ Marine \& Environmental Research (MER) Lab, 202 Amathountos Av, Marina Gardens, Block B, Off. 13-14, Limassol, Cyprus

Full list of author information is available at the end of the article
}

2001 and these have expanded their geographical range during this time (Zenetos et al. 2012). The bluespotted cornetfish Fistularia commersonii colonised almost the entire Mediterranean in just 7 years (Azzurro et al. 2012) where it now poses a threat to local ecosystems since it feeds on a large variety of prey (41 taxa) and specialises on juveniles of the commercial fish Boops boops and Spicara smaris (Bariche et al. 2009). The pufferfish Lagocephalus sceleratus has now reached the central Mediterranean (Azzurro et al. 2014) and is expanding west (Souissi et al. 2014). It eats economically important cephalopods Sepia officinalis and Octopus vulgaris (Cuvier 1797) and is classed as a fisheries pest (Kalogirou 2013). Some countries have initiated invasive fish eradication programmes, for example the Cypriot authorities have been compensating fishermen for their pufferfish catches during the reproductive season, resulting in massive removals of pufferfish biomass from the eastern Mediterranean (Rousou et al. 2014).

Few worldwide fish invasions of similar magnitude are documented; the introduction of the red lionfish Pterois volitans and the devil firefish $P$. miles in the western Atlantic is one of the fastest and most ecologically harmful marine fish introductions to date (Albins \& Hixon 2013). In their native range, P. miles 
occur in the Indian Ocean from South Africa to the Red Sea and Persian Gulf, and east to Sumatra while $P$. volitans are observed in both the western and central Pacific and western Australia. Pterois volitans looks similar to $P$. miles but has an additional dorsal fin ray and an extra anal fin ray (Schultz 1986). A decade after either intentional or accidental aquarium release in Florida, $P$. volitans became fully established throughout the southeast United States and the Caribbean Sea, extending to South America and much of the Gulf of Mexico (Schofield et al. 2015). The alien lionfish population has low genetic diversity and is thought to originate from a small founder population in the southeast United States (Betancur-R et al. 2011). The lionfish are generalist carnivores and can feed on a large variety of fish and crustaceans although large individuals prey almost exclusively on fish (Côté et al. 2013b). Lionfish spawn every 4 days year-round, producing around two million buoyant gelatinous eggs per year (Morris et al. 2009). Their eggs are planktonic and can ride the ocean currents and cover large distances for about a month before they settle (Ahrenholz \& Morris 2010). In western Atlantic, lionfish are more abundant than in their native region and have become the dominant predator on coral reefs with a great impact on native reef fishes, decreasing the abundance of $>40$ prey species by $65 \%$ on average, in just 2 years (Green et al. 2012). Their dramatic invasive success results from a combination of factors such as early maturation and reproduction, anti-predatory venomous defences and ecological versatility of the lionfish coupled with naive prey and the overfishing of native predators (Côté et al. 2013a).

In the Mediterranean Sea, one P. miles was recorded in 1991 off Israel (Golani \& Sonin 1992). After two decades of silence, two specimens were captured off the coast of Lebanon in 2012 (Bariche et al. 2013). Soon after, two more were reported in a newspaper article, captured off Cyprus and in 2014, another specimen was sighted in Turkey, then in 2015 two more were captured in Cyprus and then sighted in Rhodes in Greece (Turan et al. 2014; Oray et al. 2015; Crocetta et al. 2015; Iglésias \& Frotté 2015). Recently, several records were reported from south Turkey indicating a westerly migration of the species towards the Aegean Sea (Turan \& Öztürk 2015). Hitherto, lionfish were reported only occasionally in the eastern Mediterranean Sea and their successful invasion in the Mediterranean Sea is questionable due to unfavourable oceanographic conditions that limit the wide dispersion of lionfish larvae (Johnston \& Purkis 2014).

In this article, we present evidence that the threat of lionfish invasion in the eastern Mediterranean Sea is real and is probably underway. Sightings of the lionfish $P$. miles from the coastal waters of south Cyprus are becoming more frequent in contrast to recent model predictions (Poursanidis 2015). Furthermore, groups of lionfish have been sighted together for the first time in the Mediterranean.

\section{Materials and methods}

In 2015 reports of lionfish sightings on electronic social media/networks and within the local community of divers and fishermen became more frequent. To map lionfish distribution around Cyprus, we collated information from local divers and spearfishermen who reported lionfish encounters in the coastal waters. In-person and telephone interviews were conducted. Interviewees with proof of lionfish sightings willingly provided the evidence (photographs and/or videos) for the purposes of this study. Date of sighting, locality (area and depth) and other information were recorded for validated lionfish sightings. In addition, governmental officers of the Department of Fisheries and Marine Research (DFMR) of the Ministry of Agriculture, Rural Development and Environment shared information and specimens captured in trammel nets by local coastal fishermen.

\section{Results}

The lionfish $P$. miles has spread rapidly and colonised almost the entire south eastern coast of Cyprus, from Limassol (south) to Protaras (south east) in just 1 year (Fig. 1). Divers and government officers that were questioned in this study mentioned $>10$ additional lionfish sightings and captures that were unfortunately not photographed so are not included in our database.

Officers from DFMR provided four specimens for the purposes of this study. One is now alive in an aquarium at DFMR offices and another is among the first two undocumented reports made from Cyprus back in February 2013 (Bariche et al. 2013). More details about these specimens are presented in Fig. 2. Most validated reports of lionfish come from scuba divers and freedivers across south Cyprus. Here we list 24 new sightings of at least 19 different fish (Fig. 3, Table 1).

Three pairs of lionfish have been photographed, one at Zenobia wreck at $20 \mathrm{~m}$ depth, another near Cape Kiti at 42-43 m (Photo D, Fig. 3) and one more at Cyclops caves near Cape Greco at 12-15 m depth. The Cyclops pair has been photographed many times by different recreational scuba divers both as singletons or together (Photos C, I, J, O, Q, W and X, Fig. 3). The distinctive stripe pattern of these two individuals allows their identification through photos and the tracking of their movement. They were documented together at the same rock formation for a period of 2 months between July and September 2015 (Photos O, Q, W and X, Fig. 3). It is noteworthy that one individual from the pair named $\beta$ with a unique stripe pattern on its left side, may have been reported on the other side of Cape Greco, around $10 \mathrm{~km}$ 


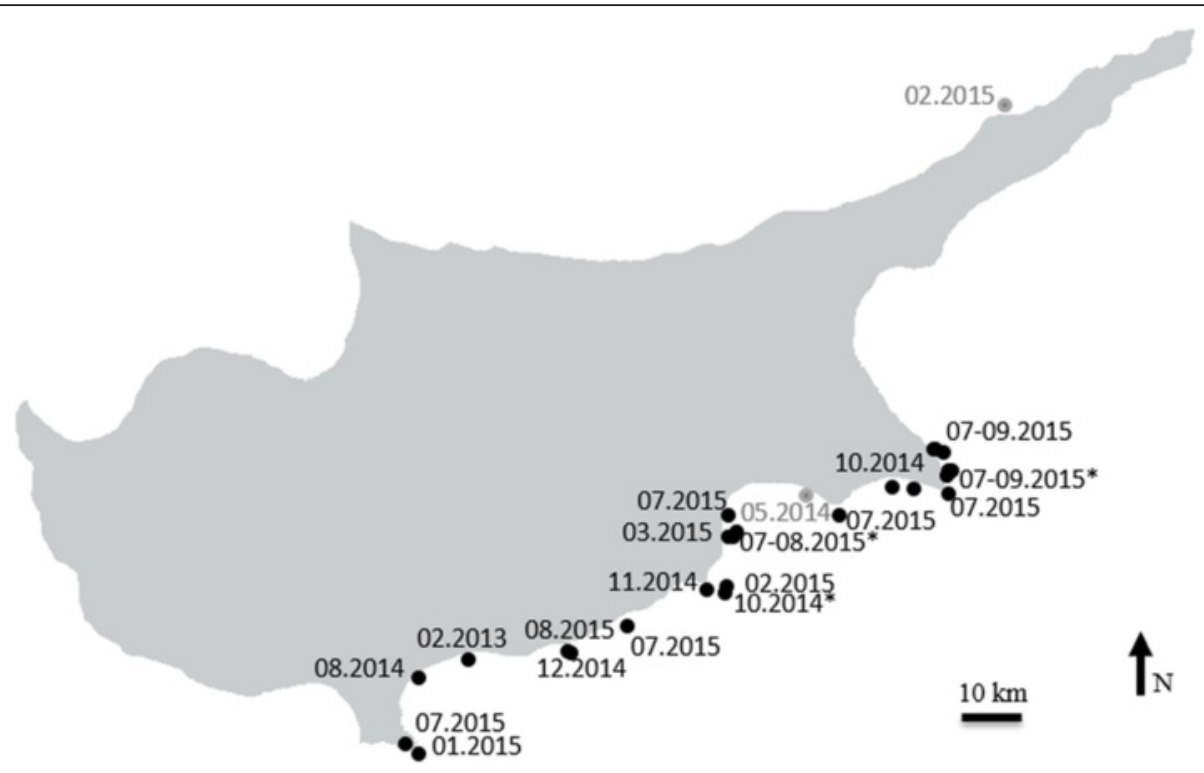

Fig. 1 Updated lionfish reports from the island of Cyprus. Oray et al. (2015) and Iglésias \& Frotté (2015) sightings are presented in grey. Locality points on the map are roughly estimated based on the information provided by the person who reported the lionfish sighting. ${ }^{*}$ indicates the presence of a lionfish pair

from Cyclops caves, several months earlier in October 2014 (Photo C, Fig. 3). The other individual, named $\alpha$, has very distinctive stripes on its right side and was first sighted at Cyclops caves on 7 of July 2015 and the next day it was reported towards Green bay, about $2 \mathrm{~km}$ to the north east (Photos I and J, Fig. 3). Two weeks later it was found back at Cyclops caves with $\beta$ where they remained together for at least 2 months. About a week before the pairing was sighted at Cyclops caves, a third lionfish was reported at the site but it was not sighted again thereafter (Photo L, Fig. 3). Recently, a different lionfish has joined the pair (Photo X, Fig. 3).

\section{Discussion}

The possibility of a lionfish invasion in the Mediterranean Sea and the potential ecological and socio-economic impacts that may follow have been largely neglected by the regional scientific community, managers and other stakeholders. Few validated reports of lionfish sightings exist from the region, which creates muted concern and uncertainty about the ability of the species to colonise the Mediterranean. Furthermore, model simulations have suggested that this would be unlikely to happen (Johnston \& Purkis 2014) although the warming and acidification of Mediterranean waters due to $\mathrm{CO}_{2}$ emissions may require

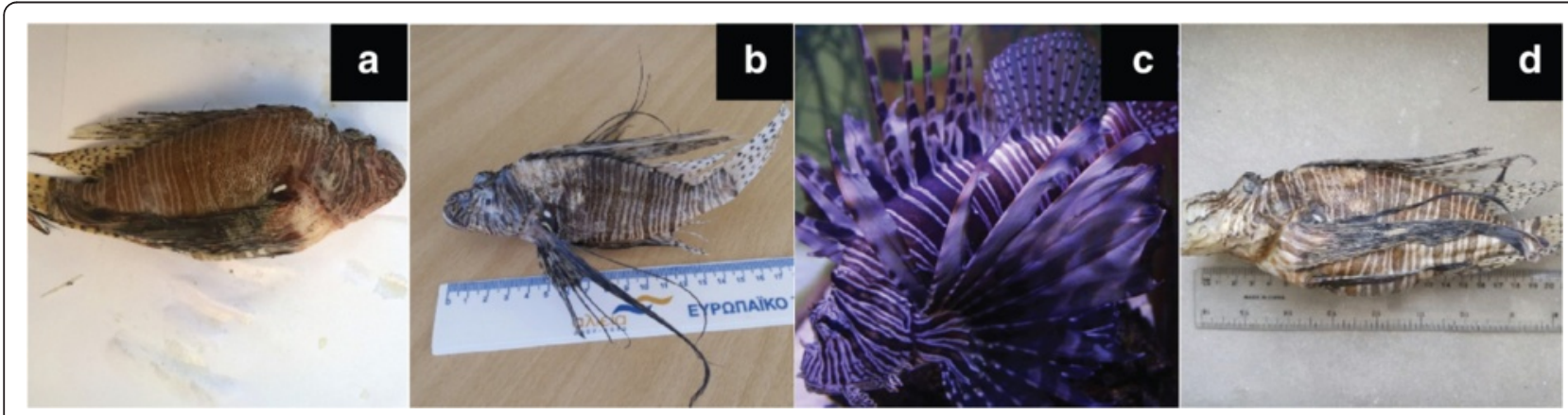

Fig. 2 Photographs of lionfish from the south Cyprus captured by professional fishermen using trammel nets. a was captured in Amathounta, Limassol in February 2013 and it is one of the first two lionfish that were reported in Cyprus (Bariche et al. 2013); b was captured at Cape Gata, Akrotiri, Limassol in January 2015 at the depth of 15 m; c is a living specimen captured at Cape Kiti, Larnaca in May 2015 at the depth of 40 m; d was captured at Ayios Theodoros near Zygi in July 2015 at the depth of $15 \mathrm{~m}$ 

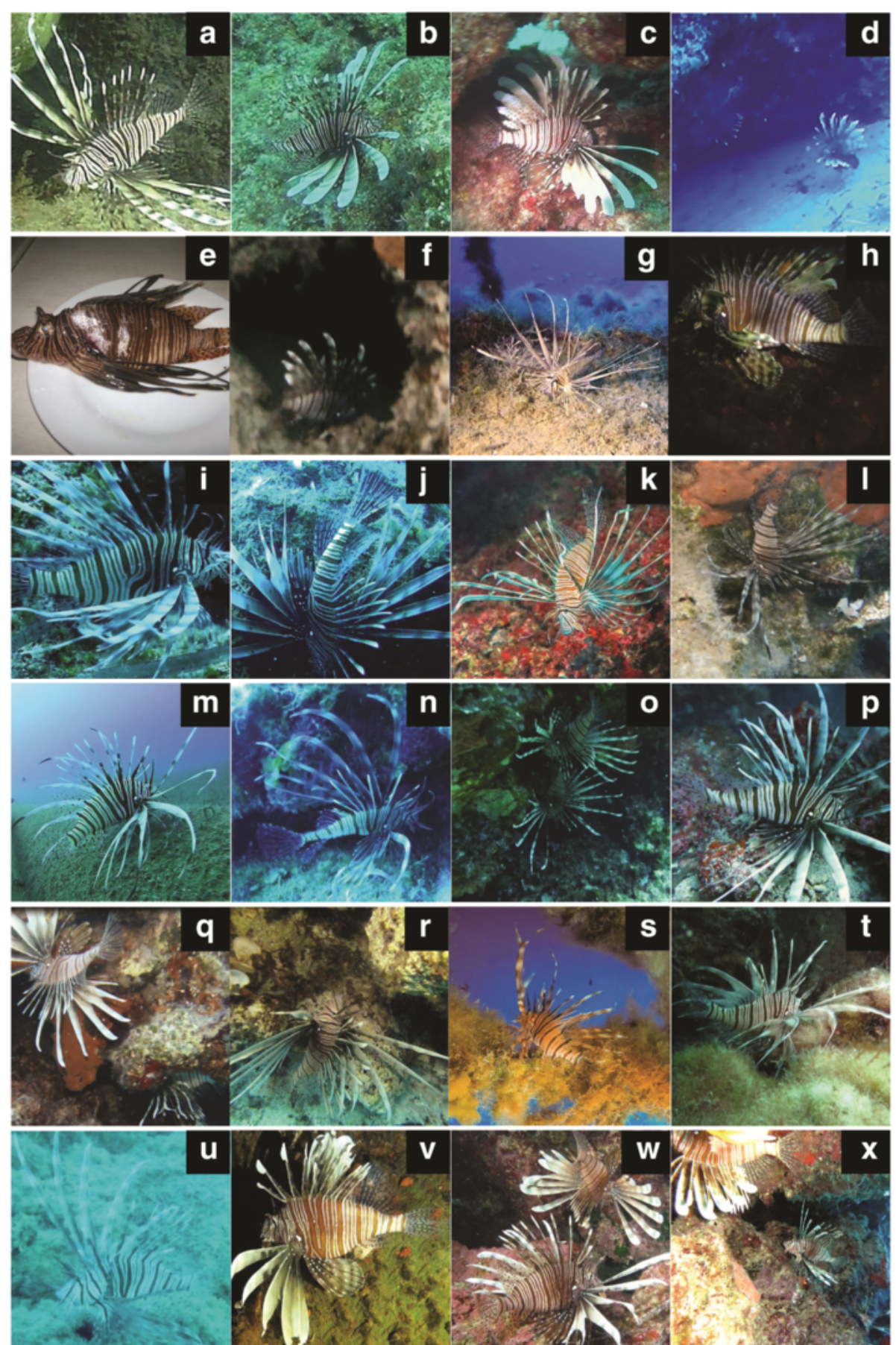

Fig. 3 Photographs of lionfish from the south coast of Cyprus captured by recreational scuba divers, free-divers or spear-fishermen. Further details on Table 1

new modelling approaches (Hall-Spencer \& Allen 2015). The lionfish first appeared in the eastern Mediterranean at about the same time that they were first reported off Florida. There they spread rapidly and colonised almost all warm parts of the east coast of United States, the Gulf of Mexico and the entire Caribbean Sea (Schofield et al.
2015) whereas more than two decades passed for a second sighting to occur in the Mediterranean Sea.

Here, we present $>20$ lionfish sightings (mostly by divers) from the coastal waters of south Cyprus during over the past year, providing evidence that the lionfish invasion in the Mediterranean Sea is becoming a clear threat that 
Table 1 Lionfish sightings details from divers who took the photographs in Fig. 3. Coordinates are best available estimates

\begin{tabular}{|c|c|c|c|c|c|c|c|c|}
\hline Photo & Date & Recorded by & $\begin{array}{l}\text { Method of } \\
\text { detection }\end{array}$ & Site & $\begin{array}{l}\text { Depth } \\
\text { (m) }\end{array}$ & $\begin{array}{l}\text { Type of } \\
\text { substrate }\end{array}$ & $\begin{array}{l}\text { Latitude } \\
(\mathrm{N})\end{array}$ & $\begin{array}{l}\text { Longitude } \\
\text { (E) }\end{array}$ \\
\hline A & 28.08.2014 & Stathis Georgiou & $\begin{array}{l}\text { Freediving/ } \\
\text { Spearfishing }\end{array}$ & $\begin{array}{l}\text { Limassol Marina (external side of } \\
\text { wave breakers) }\end{array}$ & 15 & Artificial hard & $34^{\circ} 39.9^{\prime}$ & $33^{\circ} 2.4^{\prime}$ \\
\hline B & 08.10 .2014 & Tasos Charalambous & $\begin{array}{l}\text { Freediving/ } \\
\text { Spearfishing }\end{array}$ & Near Ayia Napa port, Famagusta & 09-10 & Natural hard & $34^{\circ} 58.8^{\prime}$ & $34^{\circ} 0.3^{\prime}$ \\
\hline C & 15.10 .2014 & Tasos Charalambous & $\begin{array}{l}\text { Freediving/ } \\
\text { Spearfishing }\end{array}$ & $\begin{array}{l}2 \text { km from Ayia Napa port towards } \\
\text { Cape Greco, Famagusta }\end{array}$ & $10-11$ & Natural hard & $34^{\circ} 58.4^{\prime}$ & $34^{\circ} 1.8^{\prime}$ \\
\hline D & 25.10 .2014 & George Vasiliou & $\begin{array}{l}\text { Freediving/ } \\
\text { Spearfishing }\end{array}$ & Cape Kiti, Larnaca & $42-43$ & Natural hard & $34^{\circ} 49.6^{\prime}$ & $33^{\circ} 38.4^{\prime}$ \\
\hline E & 23.11 .2014 & $\begin{array}{l}\text { Constantinos } \\
\text { Afxentiou }\end{array}$ & $\begin{array}{l}\text { Freediving/ } \\
\text { Spearfishing }\end{array}$ & Cape Kiti, Larnaca & 10 & Natural hard & $34^{\circ} 48.7^{\prime}$ & $33^{\circ} 36.3^{\prime}$ \\
\hline $\mathrm{F}$ & 20.12.2014 & Giannis loannou & $\begin{array}{l}\text { Freediving/ } \\
\text { Spearfishing }\end{array}$ & $\begin{array}{l}\text { Vasiliko Port (external side of wave } \\
\text { breakers), Larnaca }\end{array}$ & 5 & Artificial hard & $34^{\circ} 42.9^{\prime}$ & $33^{\circ} 19.0^{\prime}$ \\
\hline G & 28.03.2015 & Andreas Makris & $\begin{array}{l}\text { Recreational } \\
\text { scuba diving }\end{array}$ & Alexandria Wreck, Larnaca & 30 & Wreck & $34^{\circ} 53.6^{\prime}$ & $33^{\circ} 39.2^{\prime}$ \\
\hline H & 05.07 .2015 & George Pavlides & $\begin{array}{l}\text { Freediving/ } \\
\text { Spearfishing }\end{array}$ & Akrotiri, Limassol & 13 & Natural hard & $34^{\circ} 33.0^{\prime}$ & $33^{\circ} 1.0^{\prime}$ \\
\hline | & 07.07.2015 & Vagelis Gavalas & $\begin{array}{l}\text { Recreational } \\
\text { scuba diving }\end{array}$ & Cyclops Caves, Protaras, Famagusta & 13 & Natural hard & $34^{\circ} 59.1^{\prime}$ & $34^{\circ} 4.6^{\prime}$ \\
\hline J & 08.07.2015 & Wolf Werner & $\begin{array}{l}\text { Recreational } \\
\text { scuba diving }\end{array}$ & Green Bay, Protaras, Famagusta & 12 & Natural hard & $35^{\circ} 0.1^{\prime}$ & $34^{\circ} 4.1^{\prime}$ \\
\hline K & 10.07 .2015 & Maria Papanikola & $\begin{array}{l}\text { Recreational } \\
\text { scuba diving }\end{array}$ & Cape Greco, Famagusta & 10 & Natural hard & $34^{\circ} 57.7^{\prime}$ & $34^{\circ} 4.4^{\prime}$ \\
\hline L & 16.07.2015 & Wolf Werner & $\begin{array}{l}\text { Recreational } \\
\text { scuba diving }\end{array}$ & Cyclops Caves, Protaras, Famagusta & 9 & Natural hard & $34^{\circ} 59.1^{\prime}$ & $34^{\circ} 4.6^{\prime}$ \\
\hline M & 18.07.2015 & Elia Sotiris & $\begin{array}{l}\text { Freediving/ } \\
\text { Spearfishing }\end{array}$ & Oil pipeline, near Larnaca port & 16 & Pipeline & $34^{\circ} 56.2^{\prime}$ & $33^{\circ} 39.0^{\prime}$ \\
\hline N & 19.07.2015 & Sotiroula Tsirponouri & $\begin{array}{l}\text { Recreational } \\
\text { scuba diving }\end{array}$ & Zenobia Wreck, Larnaca & 20 & Wreck & $34^{\circ} 53.8^{\prime}$ & $33^{\circ} 39.5^{\prime}$ \\
\hline O & 21.07.2015 & Vagelis Gavalas & $\begin{array}{l}\text { Recreational } \\
\text { scuba diving }\end{array}$ & Cyclops Caves, Protaras, Famagusta & $12-14$ & Natural hard & $34^{\circ} 59.1^{\prime}$ & $34^{\circ} 4.6^{\prime}$ \\
\hline P & 25.07.2015 & Maria Papanikola & $\begin{array}{l}\text { Recreational } \\
\text { scuba diving }\end{array}$ & Xylofagou, Larnaca & 14 & Natural hard & $34^{\circ} 56.7^{\prime}$ & $33^{\circ} 50.2^{\prime}$ \\
\hline Q & 05.08 .2015 & Wolf Werner & $\begin{array}{l}\text { Recreational } \\
\text { scuba diving }\end{array}$ & Cyclops Caves, Protaras, Famagusta & 14 & Natural hard & $34^{\circ} 59.1^{\prime}$ & $34^{\circ} 4.6^{\prime}$ \\
\hline $\mathrm{R}$ & 07.08 .2015 & Wolf Werner & $\begin{array}{l}\text { Recreational } \\
\text { scuba diving }\end{array}$ & Konnos Bay, Protaras, Famagusta & 12 & Natural hard & $34^{\circ} 59.3^{\prime}$ & $34^{\circ} 4.7^{\prime}$ \\
\hline$S$ & 09.08 .2015 & Loizos Loizou & $\begin{array}{l}\text { Recreational } \\
\text { scuba diving }\end{array}$ & Zenobia Wreck, Larnaca & 20 & Wreck & $34^{\circ} 53.8^{\prime}$ & $33^{\circ} 39.5^{\prime}$ \\
\hline $\mathrm{T}$ & 17.08 .2015 & Vagelis Gavalas & $\begin{array}{l}\text { Recreational } \\
\text { scuba diving }\end{array}$ & Green Bay, Protaras, Famagusta & 03-04 & Natural hard & $35^{\circ} 0.1^{\prime}$ & $34^{\circ} 4.1^{\prime}$ \\
\hline U & 20.08 .2015 & Andreas Gkinos & $\begin{array}{l}\text { Freediving/ } \\
\text { Spearfishing }\end{array}$ & $\begin{array}{l}\text { Vasiliko Port (external side of wave } \\
\text { breakers), Larnaca }\end{array}$ & 14 & Artificial hard & $34^{\circ} 42.9^{\prime}$ & $33^{\circ} 19.0^{\prime}$ \\
\hline V & 29.08 .2015 & Wolf Werner & $\begin{array}{l}\text { Recreational } \\
\text { scuba diving }\end{array}$ & Zenovia wreck, Larnaca & $20-22$ & Wreck & $34^{\circ} 53.8^{\prime}$ & $33^{\circ} 39.5^{\prime}$ \\
\hline W & 08.09 .2015 & Vagelis Gavalas & $\begin{array}{l}\text { Recreational } \\
\text { scuba diving }\end{array}$ & Cyclops Caves, Protaras, Famagusta & 14 & Natural hard & $34^{\circ} 59.1^{\prime}$ & $34^{\circ} 4.6^{\prime}$ \\
\hline$x$ & 21.09.2015 & Royce Hatch & $\begin{array}{l}\text { Recreational } \\
\text { scuba diving }\end{array}$ & Cyclops Caves, Protaras, Famagusta & 15 & Narural hard & $34^{\circ} 59.1^{\prime}$ & $34^{\circ} 4.6^{\prime}$ \\
\hline
\end{tabular}

requires the immediate attention of officials and the engagement of stakeholders. It appears that the lionfish have found their niche, formed reproductive populations and are now established. Lionfish are normally solitary animals and only gather in groups to mate (Fishelson 1975). While some lionfish stay put, like one that remained on the Zenobia wreck for at least 6 weeks, some travel up to $2 \mathrm{~km}$ a day ( $\alpha$ from the Cyclops pair). 
In the western Atlantic, lionfish have been found in a wide variety of habitats including hard bottom and patchy reefs, seagrass beds and wrecks (Claydon et al. 2012). The lionfish reported in this study were found at depths ranging from 3 to $43 \mathrm{~m}$ and the majority were found on vertical rock walls or at the entrance of small caves. Three were found on breakwater defences, three were on wrecks and one was spearfished near an oil pipeline. So far, no lionfish have been spotted in seagrass Posidonia oceanica (Linnaeus) Delile 1813 meadows. Genetic research is needed to assess dispersion pathways of the lionfish and to find out whether they have come from Lessepsian migration and/or through aquarium release.

Lionfish have very few documented natural predators due to their venomous spines. Native groupers in the western Atlantic have learned to eat this non-indigenous species (Maljković et al. 2008) and in at least three cases reported herein groupers have been seen close to lionfish. It remains to be seen whether native groupers such as Epinephelus marginatus will learn to prey on lionfish and control their invasion. Restrictions on fishing seem sensible to help threatened IUCN Red List species such as the Mediterranean dusky grouper, as these may in turn help control the spread of invasive fish (Mumby et al. 2011).

Judging from the recent increase in P. miles in the eastern Mediterranean Sea, its few natural predators, the dispersal capabilities of their planktonic larvae and its ability to adapt to a range of habitats, we suspect that a rapid expansion throughout the Mediterranean Sea may soon follow with significant impacts on local ecosystems and fisheries. Furthermore, $\mathrm{CO}_{2}$ emissions which are warming the Mediterranean Sea and the construction of a deeper and wider Suez Canal are expected to increase invasion rates (Galil et al. 2015; Hall-Spencer \& Allen 2015).

Lionfish are slow moving and easy to collect by divers and we know, from the western Atlantic experience, that early detection and a rapid response is the first line of defence to mitigate impacts of the lionfish invasion (Morris et al. 2009). Targeted removal by divers has reduced lionfish abundance at shallow depths in the western Atlantic (Frazer et al. 2012; Albins \& Hixon 2013). Mediterranean stakeholders (especially divers and fishermen) should be engaged with education and outreach, training and the provision of incentives for removal efforts. The fact that only about a tenth of the lionfish reported by divers in this study were removed from the ecosystem is testimony to the lack of knowledge about the potential impacts of a lionfish invasion. We believe that many will be motivated to aid removal efforts. When the venomous dorsal, pelvic fin and anal fin spines are removed, the lionfish is safe to consume and this can be promoted. Removal programs should be combined with efforts to restore populations of potential predators of lionfish, such as the dusky grouper.

\section{Abbreviations}

$\mathrm{CO}_{2}$, carbon dioxide; DFMR, Department of Fisheries and Marine Research; IUCN, International Union for Conservation of Nature

\section{Acknowledgements}

We are grateful to all those who have helped collect and shared information about the lionfish sightings from south Cyprus, especially those listed in Table 1, who contributed photographs and knowledge. We also thank Charalampos Antoniou and officers Nikolas Michailides, Kostas Konnari and George loannou of the Department of Fisheries and Marine Research, who kindly shared information about reported lionfish catches by fishermen and provided specimens and photographs.

\section{Funding}

No funding sources.

Availability of data and materials

All available data are presented in the manuscript.

\section{Authors' contributions}

DK communicated with officials, divers and fishermen and collected data regarding the lionfish encounters. He was the main author of the article. JHS edited and reviewed the article and supervised the article preparation. PK assisted data collection and reporting. All authors read and approved the final manuscript.

\section{Competing interests}

The authors declare that they have no competing interests.

\section{Author details}

${ }^{1}$ School of Marine Science and Engineering, Plymouth University, Plymouth, UK. ${ }^{2}$ Marine \& Environmental Research (MER) Lab, 202 Amathountos Av, Marina Gardens, Block B, Off. 13-14, Limassol, Cyprus. ${ }^{3}$ Shimoda Marine Research Centre, Tsukuba University, Tsukuba, Japan.

Received: 15 September 2015 Accepted: 28 January 2016 Published online: 30 June 2016

\section{References}

Ahrenholz DW, Morris JA. Larval duration of the lionfish, Pterois volitans along the Bahamian Archipelago. Environ Biol Fish. 2010;88:305-9.

Albins MA, Hixon MA. Worst case scenario: potential long-term effects of invasive predatory lionfish (Pterois volitans) on Atlantic and Caribbean coral-reef communities. Environ Biol Fish. 2013;96:1151-7.

Azzurro E, Soto S, Garofalo G, Maynou F. Fistularia commersonii in the Mediterranean Sea: invasion history and distribution modeling based on presence-only records. Biol Invasions. 2012;15:977-90.

Azzurro E, Castriota L, Falautano M, Giardina F, Andaloro F. The silver-cheeked toadfish Lagocephalus sceleratus (Gmelin, 1789) reaches Italian waters. J Appl Ichthyol. 2014;30:1050-2.

Bariche M, Alwan N, El-Assi H, Zurayk R. Diet composition of the Lessepsian bluespotted cornetfish Fistularia commersonii in the eastern Mediterranean. J Appl Ichthyol. 2009;25:460-5.

Bariche M, Torres M, Azzurro E. The presence of the invasive Lionfish Pterois miles in the Mediterranean Sea. Mediterr Mar Sci. 2013;14:292-4.

Betancur-R R, Hines A, Acero A, Ortı G, Wilbur AE, Freshwater DW. Reconstructing the lionfish invasion: insights into Greater Caribbean biogeography. J Biogeogr. 2011;38:1281-93.

Claydon JAB, Calosso MC, Traiger SB. Progression of invasive lionfish in seagrass, mangrove and reef habitats. Mar Ecol Prog Ser. 2012;448:119-29.

Coll M, Piroddi C, Steenbeek J, Kaschner K, Ben Rais Lasram F, Aguzzi J, Ballesteros E, Bianchi CN, Corbera J, Dailianis T, Danovaro R, Estrada M, Froglia C, Galil BS, Gasol JM, Gertwagen R, Gil J, Guilhaumon F, Kesner-Reyes K, Kitsos MS, Koukouras A, Lampadariou N, Laxamana E, López-Fé de la Cuadra CM, Lotze HK, Martin D, Mouillot D, Oro D, Raicevich S, Rius-Barile J, Saiz-Salinas Jl., San Vicente C, Somot S, Templado J, Turon X, Vafidis D, Villanueva R, Voultsiadou E. The biodiversity of the Mediterranean Sea: estimates, patterns, and threats. PLoS ONE. 2010;5:e11842. doi:10.1371/ journal.pone.0011842

Côté IM, Green SJ, Hixon MA. Predatory fish invaders: Insights from Indo-Pacific lionfish in the western Atlantic and Caribbean. Biol Conserv. 2013a;164:50-61. 
Côté IM, Green SJ, Morris Jr JA, Akins JL, Steinke D. Diet richness of invasive Indo-Pacific lionfish revealed by DNA barcoding. Mar Ecol Prog Ser. 2013b; 472:249-56.

Crocetta F, Agius D, Balistreri P, Bariche M, Bayhan Y, Cakir M, Ciriaco S, Corsini-Foka M, Deidun A, El Zrelli R, Ergüden D, Evans J, Ghelia M, Giavasi M, Kleitou P, Kondylatos G, Lipej L, Mifsud C, Özvarol Y, Pagano A, Portelli P, Poursanidis D, Rabaoui L, Schembri P, Taşkin E, Tiralongo F, Zenetos A. New Mediterranean Biodiversity Records (October 2015). Mediterr Mar Sci. 2015;16:682-702.

Fishelson L. (1975) Ethology and reproduction of pteroid fishes found in the gulf of Aqaba (Red Sea), especially Dendrochirus brachypterus (Cuvier), (Pteroidae, Teleostei). Eight European Marine Biology Symposium. Sorrento (Naples) 1973. Pubblicazioni della Stazione Zoologica, Napoli 39 (Suppl. 1), pp. 635-656

Frazer TK, Jacoby CA, Edwards MA, Barry SC, Manfrino CM. Coping with the lionfish invasion: can targeted removals yield beneficial effects? Rev Fish Sci. 2012;20:185-91.

Galil BS, Boero F, Campbell ML, Carlton JT, Cook E, Fraschetti S, Gollasch S, Hewitt CL, Jelmert A, Macpherson E, Marchini A, McKenzie C, Minchin D, Occhipinti-Ambrogi A, Ojaveer H, Olenin S, Piraino S, Ruiz GM. 'Double trouble': the expansion of the Suez Canal and marine bioinvasions in the Mediterranean Sea. Biol Invasions. 2015;17:973-6.

Golani D, Sonin O. New records of the Red Sea fishes, Pterois miles (Scorpaenidae) and Pteragogus pelycus (Labridae) from the eastern Mediterranean Sea. Ichthyol Res. 1992;39:167-9.

Green S, Akins J, Maljkovic A, Côté IM, Goldstien SJ. Invasive lionfish drive Atlantic coral reef fish declines. PLOS ONE. 2012;7:e32596. doi:10.1371/journal.pone. 0032596.

Hall-Spencer JM, Allen R. The impact of ocean acidification on 'nuisance' species. Res Rep Biodivers Stud. 2015:4:33-46.

Iglésias PS, Frotté L. Alien marine fishes in Cyprus: update and new records. Aquat Invasions. 2015;10:425-38.

Johnston MW, Purkis SJ. Are lionfish set for a Mediterranean invasion? Modelling explains why this is unlikely to occur. Mar Pollut Bull. 2014;88:138-47.

Kalogirou S. Ecological characteristics of the invasive pufferfish Lagocephalus sceleratus (Gmelin, 1789) in the eastern Mediterranean Sea-a case study from Rhodes. Mediterr Mar Sci. 2013;14:251-60.

Katsanevakis S, Coll M, Piroddi C, Steenbeek J, Ben Rais LF, Zenetos A, Cardoso AC. Invading the Mediterranean Sea: biodiversity patterns shaped by human activities. Front Mar Sci. 2014;1:32. doi:10.3389/fmars.2014.00032.

Kletou D, Hall-Spencer JM. Threats to ultraoligotrophic marine ecosystems. In: Dr. Cruzado A, editor. Marine Ecosystems. 2012. p. 1-34.

Lejeusne $C$, Chevaldonné P, Pergent-Martini C, Boudouresque CF, Perez T. Climate change effects on a miniature ocean: the highly diverse, highly impacted Mediterranean Sea. Trends Ecol Evol. 2010;25:250-60.

Maljković A, Van Leeuwen T, Cove S. Predation on the invasive red lionfish, Pterois volitans (Pisces: Scorpaenidae), by native groupers in the Bahamas. Coral Reefs. 2008;27:501.

Montefalcone M, Morri C, Parravicini V, Bianchi CN. A tale of two invaders: divergent spreading kinetics of the alien green algae Caulerpa taxifolia and Caulerpa cylindracea. Biol Invasions. 2015;17:2717-28.

Morris Jr JA, Akins JL, Barse A, Cerino D, Freshwater DW, Green SJ, Muñoz RC, Paris C, Whitfield PE. Biology and ecology of the invasive lionfishes, Pterois miles and Pterois volitans. Proc Gulf Caribb Fish Inst. 2009;29:409-14.

Mumby PJ, Harborne AR, Brumbaugh DR. Grouper as a natural biocontrol of invasive lionfish. PLoS ONE. 2011;6:e21510. doi:10.1371/journal.pone.0021510.

Oray I, Sınay E, Saadet Karakulak F, Yıldız T. An expected marine alien fish caught at the coast of Northern Cyprus: Pterois miles (Bennett, 1828). J Appl Ichthyol. 2015;31:733-5.

Poursanidis D. (2015) Ecological Niche Modeling of the the invasive lionfish Pterois miles (Bennett, 1828) in the Mediterranean Sea. Eleventh Panhellenic Symposium on Oceanography and Fisheries, Mytilene, Lesvos island, Greece, 13-15 May 2015. Anavyssos Attiki Greece; Hellenic Center for Marine Research, pp. 621-624.

Rousou M, Ganias K, Kletou D, Loucaides A, Tsinganis M. Maturity of the pufferfish Lagocephalus sceleratus in the southeastern Mediterranean Sea. Sex Early Dev Aquat Org. 2014;1:35-44.

Schofield P, Morris Jr J, Langston J, Fuller P. (2015) Pterois volitans/miles FactSheet. USGS Nonindigenous Aquatic Species Database [Online], Gainesville, FL. http://nas.er.usgs.gov/queries/FactSheet.aspx?speciesID=963 Revision Date: 9/18/2012. Accessed Sept 2015.

Schultz ET. Pterois volitans and Pterois miles: two valid species. Copeia. 1986;1986:686-90.
Souissi JB, Rifi M, Ghanem R, Ghozzi L, Boughedir W, Azzurro E. Lagocephalus sceleratus (Gmelin, 1789) expands through the African coasts towards the Western Mediterranean Sea: a call for awareness. Management. 2014;5:357-62.

Turan C, Öztürk B. First record of the lionfish Pterois miles from the Aegean Sea. J Black Sea/Mediterr Environ. 2015;21:334-8.

Turan C, Ergüden D, Gürlek M, Yağlıoğlu D, Uyan A, Uygur N. First record of the Indo-Pacific lionfish Pterois miles (Bennett, 1828) (Osteichthyes: Scorpaenidae) for the Turkish marine waters. J Black Sea/Mediterr Environ. 2014;20:158-63.

Zenetos A, Ballesteros E, Verlaque M. Alien species in the Mediterranean Sea by 2012. A contribution to the application of European Union's Marine Strategy Framework Directive (MSFD). Part 2. Introduction trends and pathways. Mediterr Mar Sci. 2012;13:328-52.

\section{Submit your next manuscript to BioMed Central and we will help you at every step:}

- We accept pre-submission inquiries

- Our selector tool helps you to find the most relevant journal

- We provide round the clock customer support

- Convenient online submission

- Thorough peer review

- Inclusion in PubMed and all major indexing services

- Maximum visibility for your research

Submit your manuscript at www.biomedcentral.com/submit
C Biomed Central 